\title{
Hydraulic Conductivity and Aggregation of Fine-Textured Soil Under Intensive Cattle Grazing
}

\author{
B. E. Udom ${ }^{1} \&$ B. O. Nuga ${ }^{1,2}$ \\ ${ }^{1}$ Faculty of Agriculture, Department of Crop and Soil Science, University of Port Harcourt, Port Harcourt, \\ Nigeria \\ ${ }^{2}$ Nukot Consulting Services Inc., Winnipeg, Manitoba, Canada \\ Correspondence: B. E. Udom, Faculty of Agriculture, Department of Crop and Soil Science, University of Port \\ Harcourt, P.M.B. 5323, Port Harcourt, Nigeria. E-mail: ebassidy@yahoo.com
}

Received: June 5, 2014 Accepted: June 26, 2014 Online Published: October 15, 2014

doi:10.5539/jas.v6n11p37 URL: http://dx.doi.org/10.5539/jas.v6n11p37

\begin{abstract}
Information on hydraulic conductivity and macro- and micro-aggregate stability is needed for evaluating the ease with which soils slake and erode when in contact with water. In fine-textured soils, it will provide information on ponding of water and decrease in hydraulic gradient with wetting. This study was conducted to determine changes in hydraulic conductivity and macro- and micro-aggregate stability of a fine-textured submerged soil under intense cattle grazing for 15 years. Hydraulic conductivity of the cattle grazing soil ranged from very slow $\left(0.46 \mathrm{~cm} \mathrm{hr}^{-1}\right)$ to slow $\left(19.56 \mathrm{~cm} \mathrm{hr}^{-1}\right)$ in the top $0-25 \mathrm{~cm}$ depth, and attained near zero permeability $\left(0.15 \mathrm{~cm} \mathrm{hr}^{-1}\right.$ ) before $75 \mathrm{~cm}$ depth. Permeability was rapid (21.1 to $30.06 \mathrm{~cm} \mathrm{hr}^{-1}$ ) throughout the profile in the non-cattle grazing soil. Organic residues from cattle grazing activities raised the soil total organic carbon to as high as $72 \mathrm{~g}$ $\mathrm{kg}^{-1}$ in the top 0-25 cm depth. Wet trampling of organic residues from cattle excreta induced greater soil swelling and loss of soil strength resulting in low aggregated silt and clay (ASC) and clay flocculation index (CFI) within the $25-75 \mathrm{~cm}$ depth. Clay dispersion index $(\mathrm{CDI})$ showed significant negative $(\mathrm{P}<0.05)$ relationships with mean weight diameter (MWD) of water stable aggregates and saturated hydraulic conductivity $(r=-0.631$ and -0.596 respectively). Soil parameters controlling water storage and infiltration in such soils need to be increasingly studied to increase the area of land available for crop production and reduce soil erosion since such soils usually have high chemical fertility status.
\end{abstract}

Keywords: fine-textured soil, macro and micro aggregates, hydraulic conductivity

\section{Introduction}

Hydraulic conductivity and macro and micro aggregate stability is important soil physical properties because they determine the depth that roots can penetrate and the movement of soil water and soil air. It is less commonly recognized that animals may destroy soil structure. Trampling by animals causes soil deformation through soil compaction by the high-ground pressure of hooves and soil homogenization by shear effects (Warren, Nevill, Blackburn, \& Garza, 1986). Changes in aggregate size distribution had shown to occur by cattle even on coarse-textured soil (Mulholland \& Fullen, 1991), by the grazing of sheep on clay loam (Proffitt, Bendotti, \& McGarry, 1995), by cattle trampling on pasture in the Alp (Horn, 1986) or by reindeer herding in Northern Scandinavia (Peth, Horn, \& Bolter, 2003). Intensive cattle movements on fine-textured seasonally submerged soil can affect water storage and water movement into and within the soil. When the soil is wetter than optimum for wheel traffic, excessive trampling by cattle decreased total porosity, size and continuity of the pores (Servadio, Marsili, Pagliai, Pellegrini, \& Vignozzi, 2001).

With respect to soil structure deterioration, shearing effects are most disadvantageous as shearing causes soil homogenization. When in combination with water, it also induces greater soil swelling followed by normal shrinkage behaviour and a complete loss of soil strength, which usually result in soil puddling (Pietola, Horn, \& Yli-Halla, 2005). Intensive cattle grazing on submerged soil can affect soil water content, soil water retention and soil water diffusivity as well as structural stability. Such soil usually become very hard upon drying and progressively develops polygonal cracks whose width and depth increase with time, depending upon the nature and type of clay and moisture regime. The open cracks are difficult to till, and upon tillage produce large clods weighing from few grams to few kilograms. Such clods usually have high clod breaking strength (CBS) and 
require large amount of energy to break them to prepare a fine seed bed for a proper seed-soil contact for germination (Sharma, Verman, \& Bhagat, 1995).

The build-up of organic residues from the cattle waste products is usually observed in such soils with high chemical fertility status and increased water retention. Also the drying characteristics of the soil usually indicate delayed surface drying. The percentage of organic carbon in the whole soil due to residues from the cattle may be higher than the organic carbon in the water stable aggregates. Thus, it may take several years for the added organic carbon to enter into the soil particles and stabilize macro-aggregates. In such cases, information is needed on the aggregated particles of the soil.

It is well established that macro aggregate stability is crucial for infiltration into wet soils (Peth et al., 2003). In fine-textured soils, deformation of soil structure and aggregates increases the ponding of water and surface runoff (Proffitt et al., 1995) and, consequently increases the vulnerability of soil to water erosion. The huge animal excreta can form a biological mat, resulting in delayed infiltration. It can be speculated that intensive cattle grazing promote deformation of soil structure and accumulation of partially decomposed organic matter in the soil, and that such soils are either underutilized or completely abandoned due to lack of adequate knowledge in defining appropriate tillage and water management practices to promote crop establishment.

A number of scholars have discussed the relevance of macro aggregates in promoting crop establishment, resistance of soil to water erosion and enhanced infiltration (Anger \& Giroux, 1996; Spaccini, Zena, Igwe, Mbagwu, \& Piccolo, 2001; Eynard, Schumacher, Linstrom, \& Malo, 2004). Soil aggregation and structural stability have also been discussed using various indices (Pietola et al., 2003), but no universal prescriptions have been offered on which of these indices is preferred. The present study aimed to use saturated hydraulic conductivity and some structural aggregation indices to quantify the effects of long term cattle grazing on a fine-textured submerged soil.

\section{Materials and Methods}

\subsection{Site Description and Sampling}

The study was carried out on a 1050 ha irrigation project site in a low-level, flood plain of Enyong Creek (Lat $05^{\circ} 16^{\prime} \mathrm{N}$ and Long $07^{\circ} 58^{\prime} \mathrm{N}$ ) in southern Nigeria. The soil is the dominant soils of the Niger Deltaic and usually classified as wetland soils. The site has been under intensive cattle grazing activities between 1994 and 2011. The area is characterized by uniformly high temperature, with mean annual minimum and maximum temperature of $28{ }^{\circ} \mathrm{C}$ and $32{ }^{\circ} \mathrm{C}$ respectively. Mean annual rainfall is more than $2400 \mathrm{~mm}$. The soil is usually submerged by flood for over four weeks at the peak of the rains. Therefore, farming is usually done during the dry season. The soil when dry usually developed polygonal cracks of varying length, width and depth with clods of high breaking strength (Figures 1 and 2). In this study, three representative locations were selected in cattle the grazing area represented by Assang 1, Assang 2, and Assang 3, and one representative location in the non- cattle grazing area, represented by Obiousiere for comparison. Disturbed and undisturbed soil samples were collected in triplicate at 0-25, 25-50 and 50-75 cm depths for determination of some physical parameters. The undisturbed soil samples were collected using metal rings measuring $6 \mathrm{~cm} \times 5 \mathrm{~cm}$ (height $\times$ diameter).

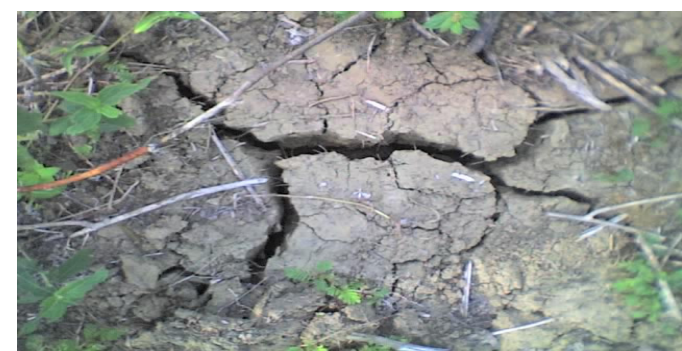

Figure 1. Polygonal cracks

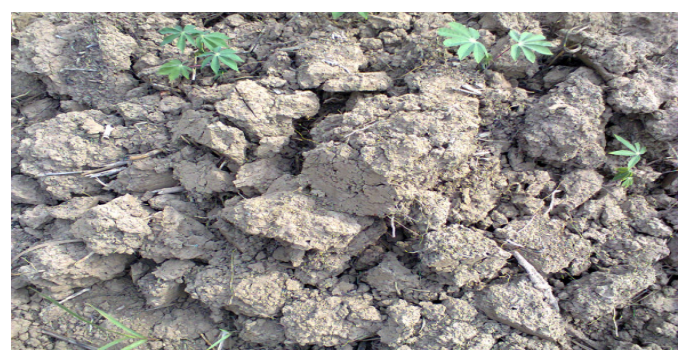

Figure 2. Clods with high breaking strength

\subsection{Determination of Particle-Size Distribution and Micro-Aggregate Stability Indices}

Particles-size distribution was determined by the hydrometer method of Gee and Bauder (1986) using sodium hexametaphosphate as dispersion agent. The clay and silt obtained from particle size analysis after complete dispersion with sodium hexametaphosphate was regarded as total clay (TC) and total silt (Tsilt), while clay and silt obtained with water were water-dispersible clay (WDC), and water-dispersible silt (WDS) respectively. 
Micro-aggregate stability indices were measured by the procedures of Dong, Chester and Simsiman (1983), calculated as:

$$
\begin{gathered}
\text { Dispersion ratio }(\mathrm{DR})=\frac{W S D+W D C}{\mathrm{~T} s i l t+T C} \\
\text { Clay dispersion index }(\mathrm{CDI})=\frac{\mathrm{WDC}}{\mathrm{TC}} \\
\text { Aggregated silt and clay }(\mathrm{ASC})=(\mathrm{TC}+\mathrm{Tsilt})-(\mathrm{WDC}+\mathrm{WDS}) \\
\text { Clay flocculation index }(\mathrm{CFI})=\frac{\mathrm{TC}-\mathrm{WDC}}{\mathrm{TC}}
\end{gathered}
$$

The higher the value of DR and CDI, the greater is the tendency of the soil to disperse upon contact with water, i.e the lower the aggregate stability when dispersion ratio (DR) and clay dispersion index (CDI) are high The higher the value of CFI and ASC, the greater the soil aggregation at micro aggregate level (Igwe \& Nwokocha, 2006).

\subsection{Determination of Saturated Hydraulic Conductivity and Water Stable Aggregates}

Saturated hydraulic conductivity was measured by the constant-head permeability test procedure of Klute and Dirksen (1986), and calculated using the transposed Darcy's equation for vertical flow of liquid.

$$
\mathrm{K}_{\mathrm{sat}}=\frac{\mathrm{Q}}{\mathrm{AT}} \times \frac{\mathrm{L}}{\Delta \mathrm{H}}
$$

Where: $\mathrm{K}_{\text {sat }}$ is saturated hydraulic conductivity $\left(\mathrm{cm} \mathrm{hr}^{-1}\right)$, $\mathrm{Q}$ is volume of water that flows through a cross-section area $\left(\mathrm{cm}^{3}\right)$, $\mathrm{A}$ is cross sectional area of core $\left(\mathrm{cm}^{2}\right), \mathrm{T}$ is time elapse $(\mathrm{sec}), \mathrm{L}$ is length of core $(\mathrm{cm})$ and $\Delta \mathrm{H}$ is hydraulic head difference $(\mathrm{cm})$.

Aggregate stability was measured by the mean weight diameter (MWD) of water stable aggregates as described by Kemper and Rosenau (1986). In this procedure $50 \mathrm{~g}$ air dried soil sample of $4.75 \mathrm{~mm}$ aggregates were placed in the top most of a nest of sieves of diameter 2, 1, 0.5, and $0.25 \mathrm{~mm}$ and pre-soaked in distilled water for 5 minutes. The aggregates were oscillated vertically in water for 30 minutes using $4 \mathrm{~cm}$ amplitude in a mechanical agitator. After wet-sieving, the resistance aggregates on each sieve and the unstable $<0.25 \mathrm{~mm}$ aggregates were quantitatively transferred into beakers, oven-dried at $50{ }^{\circ} \mathrm{C}$ for 48 hours and weighed. The mean weight diameter (MWD) of the structural aggregates was calculated as:

$$
\mathrm{MWD}=\sum_{1}^{n} x i w i
$$

Where $\mathrm{Xi}$ is the mean diameter of any particular size range of aggregates separated by sieving and Wi is the weight of aggregates in that size range as a fraction of the total dry weight of the sample analysed. Organic carbon was determined by acid dichromate wet oxidation procedure of Nelson and Sommers (1996). Conventional statistics (ANOVA) were used to assess differences in means (SPSS 10.0 for windows).

\section{Results and Discussions}

\subsection{Particle-Size Distribution, Organic Carbon and Dispersion Ratio of the Soils}

Clay content is high in all the soils exceeding $800 \mathrm{~g} \mathrm{~kg}^{-1}$ in the top $0-25 \mathrm{~cm}$ depth. This is typical of high swelling and shrinking soils with high plasticity index dominating the Niger Delta region. Organic carbon was highest $\left(72 \mathrm{mg} \mathrm{kg}^{-1}\right)$ in the top $0-25 \mathrm{~cm}$ soil in the cattle grazing soils due to high organic residues from the cattle activities (Table 1). This, however, did not translate to high aggregate stability because most of the organic carbon in the cattle grazing soils remained as discrete particles and only a part of it entered into close association with the soil aggregates. In this case, the organic residues from the cattle acts as disaggregating agent in the near water saturated soils. Earlier reported in the Northern Scandinavia soils (Peth et al., 2003), indicated that high organic residues from cattle excreta in combination with water induced greater soil swelling followed by normal shrinkage behaviour and a complete loss of soil strength. The low values of aggregated silt and clay (ASC and clay flocculating index (CFI) obtained in the cattle grazing soils (Table 2), is evidence that trampling of wet fine-textured soil by the cattle induced reduction in soil strength. 
Table 1: Particle-size distribution, organic carbon and dispersion ratio of the soils

\begin{tabular}{|c|c|c|c|c|c|c|c|}
\hline \multirow{2}{*}{ Soils } & \multirow{2}{*}{ Depth (cm) } & \multicolumn{3}{|c|}{ Particle-size distribution $\left(\mathrm{g} \mathrm{kg}^{-1}\right)$} & \multirow{2}{*}{ Texture } & \multirow{2}{*}{$\mathrm{OC}\left(\mathrm{mg} \mathrm{kg}^{-1}\right)$} & \multirow{2}{*}{ DR $(\%$} \\
\hline & & Sand $(2000-50 \mu \mathrm{m})$ & Silt $(50-2 \mu \mathrm{m})$ & Clay $(<2 \mu \mathrm{m})$ & & & \\
\hline \multirow{4}{*}{ Assang 1} & $0-25$ & 290 & 90 & 620 & $\mathrm{C}$ & 29.0 & 47 \\
\hline & $25-50$ & 150 & 10 & 840 & $\mathrm{C}$ & 5.6 & 56 \\
\hline & $50-75$ & 90 & 50 & 860 & $\mathrm{C}$ & 12.2 & 31 \\
\hline & $\mathrm{LSD}_{0.05}$ & 60 & 84 & NS & - & 6.8 & 19.08 \\
\hline \multirow{4}{*}{ Assang 2} & $0-25$ & 210 & 270 & 520 & $\mathrm{C}$ & 58.9 & 48 \\
\hline & $25-50$ & 150 & 10 & 840 & $\mathrm{C}$ & 12.2 & 54 \\
\hline & $50-75$ & 150 & 50 & 800 & $\mathrm{C}$ & 19.6 & 40 \\
\hline & $\operatorname{LSD}_{0.05}$ & NS & 62 & 190 & - & 3.5 & 12.62 \\
\hline \multirow{4}{*}{ Assang 3} & $0-25$ & 520 & 260 & 220 & SCL & 72.0 & 49 \\
\hline & $25-30$ & 150 & 30 & 820 & C & 16.0 & 56 \\
\hline & $50-75$ & 150 & 10 & 840 & $\mathrm{C}$ & 11.2 & 41 \\
\hline & $\operatorname{LSD}_{0.05}$ & 106 & 97 & 118 & - & 9.8 & 13.16 \\
\hline \multirow{4}{*}{$\begin{array}{c}\text { Obiousiere } \\
\text { (control) }\end{array}$} & $0-25$ & 240 & 110 & 650 & $\mathrm{C}$ & 27.4 & 38 \\
\hline & $25-50$ & 160 & 210 & 630 & C & 23.3 & 40 \\
\hline & $50-75$ & 140 & 230 & 630 & $\mathrm{C}$ & 10.8 & 39 \\
\hline & $\operatorname{LSD}_{0.05}$ & NS & 89 & 107 & - & 9.0 & NS \\
\hline
\end{tabular}

Table 2. Some structural stability indices of the cattle grazing and non-cattle grazing soils

\begin{tabular}{|c|c|c|c|c|c|c|c|}
\hline Soils & Depth $(\mathrm{cm})$ & MWD (mm) & $\mathrm{K}_{\mathrm{sat}}\left(\mathrm{cm} \mathrm{hr}^{-1}\right)$ & $\mathrm{ASC}(\%)$ & CDI $\left(\mathrm{g} \mathrm{g}^{-1}\right)$ & CFI $\left(\mathrm{g} \mathrm{g}^{-1}\right)$ & Permeability \\
\hline \multirow{4}{*}{ Assang 1} & $0-25$ & 1.19 & 19.56 & 33.0 & 0.09 & 0.30 & Slow \\
\hline & $25-50$ & 0.96 & 12.43 & 35.0 & 0.08 & 0.28 & Very slow \\
\hline & $50-75$ & 0.57 & 0.61 & 33.0 & 0.14 & 0.31 & Very slow \\
\hline & $\mathrm{LSD}_{0.05}$ & 0.26 & 3.24 & NS & 0.07 & NS & \\
\hline \multirow{4}{*}{ Assang 2} & $0-25$ & 0.89 & 0.76 & 37.0 & 0.10 & 0.38 & Very slow \\
\hline & $25-50$ & 0.49 & 0.48 & 41.0 & 0.11 & 0.40 & Very slow \\
\hline & $50-75$ & 0.93 & 0.15 & 38.0 & 0.23 & 0.30 & Very slow \\
\hline & $\mathrm{LS}_{0.05}$ & 0.29 & 0.22 & 5.43 & 0.05 & NS & \\
\hline \multirow{4}{*}{ Assang 3} & $0-25$ & 0.84 & 0.46 & 14.0 & 0.12 & 0.11 & Very slow \\
\hline & $25-30$ & 0.60 & 0.37 & 36.0 & 0.15 & 0.34 & Very slow \\
\hline & $50-75$ & 0.92 & 0.23 & 31.0 & 0.15 & 0.34 & Very slow \\
\hline & $\mathrm{LSD}_{0.05}$ & 0.21 & 0.11 & 8.61 & 0.07 & 0.10 & \\
\hline \multirow{4}{*}{$\begin{array}{l}\text { Obiousiere } \\
\text { (control) }\end{array}$} & $0-25$ & 1.22 & 30.06 & 31.0 & 0.09 & 0.36 & Rapid \\
\hline & $25-50$ & 1.92 & 29.20 & 26.0 & 0.08 & 0.30 & Rapid \\
\hline & $50-75$ & 0.86 & 21.1 & 26.0 & 0.08 & 0.29 & Rapid \\
\hline & $\mathrm{LSD}_{0.05}$ & 0.98 & NS & NS & NS & NS & \\
\hline
\end{tabular}

\subsection{Macro and Micro Aggregate Stability Indices}

Saturated hydraulic conductivity ranged from very slow $\left(0.46 \mathrm{~cm} \mathrm{hr}^{-1}\right)$ to slow $\left(19.56 \mathrm{~cm} \mathrm{hr}^{-1}\right)$ in the top $0-25 \mathrm{~cm}$ depth in the cattle grazing soils and rapid (21.1 to $30.6 \mathrm{~cm} \mathrm{hr}^{-1}$ ) in the non-cattle grazing soil (Table 2). The near zero permeability before $75 \mathrm{~cm}$ depth in the cattle grazing soils indicates restricting water movement in the soil. The mean weight diameter (MWD) of water stable aggregates indicates macro-aggregate stability in the $0-25 \mathrm{~cm}$ and $25-50 \mathrm{~cm}$ depths in the non-cattle grazing soil. This suggests that the cattle residues remained as discrete 
materials due to the homogenization of the submerged soil by the cattle.

Clay dispersion index (CFI) was more than $0.3 \mathrm{~g} \mathrm{~g}^{-1}$ in the $0-25 \mathrm{~cm}$ in cattle grazing soil and CDI of about $0.10 \mathrm{~g}$ $\mathrm{g}^{-1}$ in similar depth in non-cattle grazing soil (Table 2). Aggregate silt and clay (ASC) indicating colloidal stability was significantly low $(P<0.05)$ in the cattle grazing and showed non-significant $(P>0.05)$ different with depth in the non-cattle grazing soil. This result is not surprising because similar observation had earlier been made by Proffitt et al. (1995) in a fine-textured soil. The reason was that homogenization of the soil increased ponding of water resulting in surface runoff. The CFI ranged from 0.11 to $0.38 \mathrm{~g} \mathrm{~g}^{-1}$ in the $0-25 \mathrm{~cm}$ depth in cattle grazing soils, indicating low aggregation even beyond this depth. This is evidenced by the high dispersion ratio (DR) recorded in the cattle grazing soils. Low value of CFI with high DR indicates low resistance of soil aggregates to breakdown by water.

\subsection{Relationships in the Soil Macro and Micro Aggregate Indices.}

Mean weight diameter (MWD) of water stable aggregates and saturated hydraulic conductivity showed negative relationships with CDI evidencing low macro aggregate stability. Positive relationships exist between CFI and MWD and ASC and non-significant $(\mathrm{P}>0.05)$ relationship between MWD and saturated hydraulic conductivity (Table 3). This implies that increase in CFI and ASC lead to increases in macro aggregate stability and saturated hydraulic conductivity. The positive relationship $(r=0.609, \mathrm{~N}=12)$ between DR and CDI was not surprising, because the higher the CDI, the higher the tendency of the soil to disperse, meaning that partially decomposed organic residues and soil homogenization by the cattle grazing induced soil dispersion. Studies of Chevallier, Blanchart, and Feller (2004) agreed that high CDI resulted in low aggregation especially at the macro-aggregate fraction.

Mean weight diameter of water stable aggregate was significant and negatively related $(r=-0.642, \mathrm{~N}=12)$ with DR evidenced by the slow water movement within the soil due to the cattle rearing activities. Large amount of organic residues from the cattle remained in the soil as discrete particles and only a part of it entered into close association with the soil aggregate. General knowledge is that the lower the CDI the better the aggregate stability, but this colloidal stability index did not show this trend in cattle grazing soils.

Table 3. Relationships amongst macro and micro aggregate stability indices

\begin{tabular}{|c|c|c|c|c|c|c|}
\hline & \multirow{2}{*}{ MWD (mm) } & \multicolumn{3}{|c|}{ Correlation coefficient $(\mathrm{r})$} & \multirow{2}{*}{$\mathrm{CFI}\left(\mathrm{g} \mathrm{g}^{-1}\right)$} & \multirow{2}{*}{ DR $(\%)$} \\
\hline & & $\mathrm{K}_{\mathrm{sat}}\left(\mathrm{cm} \mathrm{hr}^{-1}\right)$ & $\mathrm{ASC}(\%)$ & $\mathrm{CDI}\left(\mathrm{g} \mathrm{g}^{-1}\right)$ & & \\
\hline DR (\%) & $-0.642^{*}$ & $-0.58^{*}$ & $-0.591 *$ & $0.609^{*}$ & $-0.488^{\mathrm{NS}}$ & - \\
\hline CFI $\left(\mathrm{gg}^{-1}\right)$ & $0.575^{*}$ & $0.611^{*}$ & $0.649 *$ & $-0.586^{*}$ & - & \\
\hline $\mathrm{CDI}\left(\mathrm{gg}^{-1}\right)$ & $-0.631^{*}$ & $-0.596^{*}$ & $-0.472^{\mathrm{NS}}$ & - & & \\
\hline $\operatorname{ASC}(\%)$ & $0.702 *$ & $0.624 *$ & - & & & \\
\hline $\mathrm{K}_{\text {Sat }}\left(\mathrm{cm} \mathrm{hr}^{-1}\right)$ & $0.496^{\mathrm{NS}}$ & - & & & & \\
\hline MWD (mm) & - & & & & & \\
\hline
\end{tabular}

* - Significant at $\mathrm{P}<0.05, \mathrm{NS}$ - Non significant at $\mathrm{P}>0.05$.

\section{Conclusion}

Trampling and homogenization of fine-textured submerged soil decreased water permeability by decreasing volume of water transmission pores. Zero permeability may occur before $75 \mathrm{~cm}$ depth, because of restriction in water movement leading to ponding and surface runoff. The built-up of partly decomposed organic residues due to cattle rearing activities led to the formation of biological mat. Since such soils are usually associated with high chemical fertility status, minimum tillage at low moisture content will improve the soil physical conditions for optimum crop production.

Endnotes: MWD - Mean weight diameter, ASC - Aggregate silt and clay, CDI - Clay dispersion index, $\mathrm{K}_{\text {sat }}-$ Saturated hydraulic conductivity, CFI - Clay flocculation index, DR - Dispersion ratio.

\section{References}

Anger, D. A., \& Giroux, M. (1996). Recently deposited organic matter in soil water-stable aggregates. Soil Science Society of American Journal, 62, 1185-1190. 
Chevalier, T. E., Blanchart, A. A., \& Feller, C. (2004). The physical protection of soil organic carbon in aggregates: a mechanism of carbon storage in a vertisol under pasture and market gardening (Martinique, West Indies). Agricultural Ecosystem and Environment, 103, 375-387. http://dx.doi.org/10.1016/j.agee.2003.12.009

Dong, A., Chester, A., \& Simsiman, G. V. (1983). Soil Dispersability. Soil Science, 136, 208-212. http://dx.doi.org/10.1097/00010694-198310000-00002

Eynard, A., Schumacher, T. E., Linstrom, M. J., \& Malo, D. D. (2004). Aggregate size and stability in cultivated South Dakota Praire Ustoll and Usterts. Soil Science Society of American Journal, 68,1360-1365. http://dx.doi.org/10.2136/sssaj2004.1360

Gee, G. W., \& Bauder, J. W. (1986). Particle-size analysis. In A. Klute (Ed.), Methods of Soil Analysis Part 1; Physical and Mineralogical Methods ( $2^{\text {nd }}$ ed., Agronomic Monograph 9, pp. 91-100). ASA and SSSA. Madison, W.I.

Horn, R. (1986). The influence of animal treading on soil physical properties of Mountanous soils. Mitt. Dtsch. Bodenkde Ges., 46, 63-71.

Igwe, C. A., \& Nwokocha, D. (2006). Soil organic fractions and micro-aggregation in an ultisol under cultivated and secondary forest in south-eastern Nigeria. Australian Journal of Soil Research, 44, 627-635. http://dx.doi.org/10.1071/SR05077

Kemper, D. W., \& Rosenau, R. C. (1986). Aggregate stability and size distribution. In A. Klute (Ed.), Methods of Soil Analysis (pp. 425-442). ASS and SSSA. Maidison, W.I.

Klute, A., \& Dirksen, C. (1986). Hydraulic conductivity and diffusivity: Laboratory Methods. In A. Klute (Ed.), Methods of Soil Analysis, Part 1. Physical and Mineralogical Methods (Agron. Monogr. 9, pp 687-734).

Mulholland, B., \& Fullen, M. A. (1991). Cattle trampling and soil compaction on loamy sands. Soil Use and Management, 4,189-192. http://dx.doi.org/10.1111/j.1475-2743.1991.tb00873.x

Peths, S., Horn, R., \& Bolter, M. (2003). Impacts of grazing on soil structure, water infiltration and soil heat flow as a result of reindeer herding in northern Scandinavia (pp. 911-917). Proceedings of $16^{\text {th }}$ Conference of ISTRO, 13-20 July, 2003. Brisbane, Australia.

Pietola, L., Horn, R., \& Yli-Halla, M. (2005). Effects of trampling by cattle on the hydraulic and mechanical properties of soil. Soil and Tillage Research, 82, 99-108. http://dx.doi.org/10.1016/j.still.2004.08.004

Proffitt, A. P. B., Bendotti, S., \& McGarry, D. (1995). A comparison between continuous and controlled grazing on a red duplex soil I: Effects on soil physical characteristics. Soil and Tillage Research, 35, 199-210. http://dx.doi.org/10.1016/0167-1987(95)00487-4

Servadio, P., Marsili, A., Pagliai, M., Pellegrini, S., \& Vignozzi, M. (2001). Effects on some clay soil qualities following the passage of rubber-tracked and wheel tractors in central Italy. Soil and Tillage Research, 61, 143-155. http://dx.doi.org/10.1016/S0167-1987(01)00195-7

Sharma, P. K., Verman, T. S., \& Bhagat, R. M. (1995). Soil structural improvements with additions of Lantana camara biomass in rice-wheat cropping. Soil Use Management, 11, 199-203. http://dx.doi.org/10.1111/j.1475-2743.1995.tb00956.x

Spaccini, R. A., Zena, A., Igwe, C. A., Mbagwu, J. S. C., \& Piccolo, A. (2001). Carbohydrate in water stable aggregates and particle size fractions of forested and cultivated soils of two contrasting tropical ecosystems. Biogeochemistry, 53, 1-22. http://dx.doi.org/10.1023/A:1010714919306

Warren, S. D., Nevill, M. B., Blackburn, W. H., \& Garza, N. E. (1986). Soil response to trampling under intensive rotation grazing. Soil Science Society of American Journal, 50, 1336-1340. http://dx.doi.org/10.2136/sssaj1986.03615995005000050050x

\section{Copyrights}

Copyright for this article is retained by the author(s), with first publication rights granted to the journal.

This is an open-access article distributed under the terms and conditions of the Creative Commons Attribution license (http://creativecommons.org/licenses/by/3.0/). 